\title{
Impact of Cross-Border Listing on Stock Liquidity: Evidence from East African Community
}

\author{
Stephen Matheka Makau', Samuel Owino Onyuma², Agatha Nabwire Okumu ${ }^{3}$ \\ ${ }^{1}$ Faculty of Commerce, Egerton University, Nakuru, Kenya \\ ${ }^{2}$ School of Business, Laikipia University, Nyahururu, Kenya \\ ${ }^{3}$ Finance Department, Safaricom Ltd, Nakuru Retail Centre, Kenya \\ Email address: \\ mathekamakau@gmail.com (S. M. Makau),sonyuma@laikipia.ac.ke (S. O. Onyuma), anabwire@safaricom.com (A. N. Okumu)
}

\section{To cite this article:}

Stephen Matheka Makau, Samuel Owino Onyuma, Agatha Nabwire Okumu. Impact of Cross-Border Listing on Stock Liquidity: Evidence from East African Community. Journal of Finance and Accounting. Vol. 3, No. 1, 2015, pp. 10-18. doi: 10.11648/j.jfa.20150301.12

\begin{abstract}
The purpose of this study was to examine the impact of cross listing on share liquidity for cross listed firms within East African Community, with the domestic market being the Nairobi Securities Exchange. A census was carried out for Kenyan listed firms that have cross-listed into other EAC exchanges in the last five years. Secondary data was collected from the NSE data base. Stock traded volume and turnover were used as proxy measures of stock liquidity. Their means were calculated pre- and post- cross-listing and tested for significance using a paired T-test at five percent level. Most of the results were not statistically significant. Stock liquidity improved for Equity Bank, Nation Media Group and Centum Investments measured by traded volume with that of Equity Bank and Centum being statistically significant. Kenya Commercial Bank stock liquidity declined after cross-listing, though the decline was not statistically significant. Stock liquidity measured by turnover improved for Nation Media Group and Centum shares, while it declined for Equity Bank and Kenya Commercial Bank shares after cross-listing. Again, only results for Centum was statistically significant. Overall, stock liquidity improved for Nation Media Group and Centum shares, while it declined for Equity and Kenya Commercial Bank shares. Generally, it can be concluded that cross-listing improves a firm's stock liquidity both positively and negatively according to the measure of liquidity utilized, although in most cases that impact was not statistically significant. Based on these findings, the study recommends that corporate managers should consider cross-listing for other reasons such as penetration of new markets but not to improve their stock liquidity.
\end{abstract}

Keywords: Cross-Border Listing, Stock Liquidity, Traded Volume, Stock Turnover, Nairobi Securities Exchange

\section{Introduction}

Many companies depend on equity capital to finance their businesses. A company will raise equity capital through the sale of its stock to the public by listing on a stock exchange through an Initial Public Offer (IPO). Through an IPO a company will be valued and an opening price will be set for its shares. The amount of capital that can be raised through the IPO will depend on perceived value of the shares and also on how much interest there is by investors in the shares when they are issued. An IPO will offer a company that has reached a certain size and has a strong reputation, a good route to raising a large sum of capital that will enable it to expand or invest in assets that will enable it to grow in the future. Another advantage of going public is that it results in share liquidity. Shares are considered liquid if they can be easily converted into cash. An IPO leads to share liquidity because, thereafter, the company's shares will trade on a public market, in this case the Nairobi Securities Exchange (NSE).

Cross listing refers to the listing of ordinary shares of a firm on a different exchange other than its home stock exchange. It is therefore where a firm lists its shares for trading on at least two stock exchanges located in different countries (Onyuma et al., 2012). Cross listing in East Africa has been used by regionally recognized firms such as, Kenya Airways and East African Breweries Limited (EABL) to increase their visibility and distinguish themselves from others. However this trend has changed with more firms cross listing such as Nation Media Group (NMG) and Equity Bank which are cross listed in the Dar es Salaam Stock Exchange (DSE) and Uganda Securities Exchange (USE) respectively citing more monetary and non-monetary benefits that will accrue to them if they cross list in the East African 
Community (EAC) market.

Liquidity refers to the ease of dealing in a security whether shares, options, warrants or some other instrument and turning them into cash. It can also refer to how easily shares can be bought and sold without significantly distorting the price. There are a number of different reasons as to why firms cross list from the domestic market according to Rosenboom and Van Dijk (2009), which includes market liquidity where cross listing on deeper and more liquid equity markets could lead to an increase in the liquidity of the stock and a decrease in the cost of capital.

Liquidity is seen as a major motivator for firms to cross list. This is because before cross listing the firm has to contend with the liquidity in the home market which may not satisfy the firm's financing needs. Mittoo (1992) indicates that managers of overseas companies indeed cite increased liquidity through increase in traded volume as a primary factor in their decision to list in the U.S, this is no different in the EAC market. With mass cross listing taking place in East Africa cross listing firms will be interested to know whether they will achieve this objective by cross listing.

Of recent, firms in Kenya have been increasingly crosslisting in the other EAC markets where they hope to attract investors from the region and also enjoy other benefits associated with cross-listing. This has led to increased interest in cross border listing within East Africa. When a firm cross-lists its shares, it creates investor interest and this elicits remarked changes in its traded volume, turnover and stock liquidity. Whereas evidence exists on the effect of cross border listing on financial performance and firm value, there is scanty literature on how cross border listing may affect share liquidity of the cross listing firm's shares in the EAC market. The purpose of this study was to determine whether cross border listing affects the share liquidity of a cross border listed firm in Kenya.

The findings of this study are expected to be useful to policy makers, managers and shareholders of firms contemplating to cross-list on other exchanges. The findings are useful to future researchers as it adds to the stock of knowledge in cross-listing and empirical literature corporate financing.

\section{Reviewed Literature}

\subsection{Nature of East African Securities Exchanges}

The EAC is the regional inter-governmental organization of the Republics of Kenya, Uganda, the United Republic of Tanzania, Republic of Rwanda and Republic of Burundi with its headquarters in Arusha, Tanzania. The treaty of establishment of the EAC was signed on November 1999 and entered into force on $7^{\text {th }}$ July 2000 following it's ratification by the original three partner states, Kenya, Uganda and Tanzania. The Republic of Rwanda and Republic of Burundi acceded to the EAC treaty on $18^{\text {th }}$ June 2007 and became full members with effect from $1^{\text {st }}$ July 2007.

The EAC market currently has four securities exchanges which include the NSE, USE, DSE, and RSE. The NSE is the largest securities exchange in East Africa and offers a platform for companies to list their shares in Kenya. The NSE was formed in 1954 and is one of the most active capital markets in Africa and the fourth largest Sub-Saharan Africa security exchange with 61 listed companies and 21 brokerage firms. Trading takes place on Mondays through Fridays between $10.00 \mathrm{am}$ and $3.00 \mathrm{pm}$. NSE was a regional security market up to 1972 when it lost its regional character following the nationalization, exchange control and other inter-territorial restrictions introduced in neighboring Tanzania and Uganda.

The NSE successfully installed a Central Depository System (CDS) in November 2004 and an Automated Trading System (ATS) in November 2006 (Onyuma et al., 2012). The CDS ensures that delivery and settlement is done script less while the ATS ensures that orders are matched automatically and are executed on a first come first serve basis. The NSE is regulated by the Capital Markets Authority (CMA) under the jurisdiction of the ministry of Finance. The CMA strives to ensure that companies disclose to investors all they need to know before admitting them to the bourse and on a continuous basis after listing.

The DSE is the second largest securities exchange in EAC which was incorporated in September 1996 and trading started in April 1998. Trading takes place weekly from Monday to Friday between 10:00 am and 12:00 noon. It is monitored and supervised by the Capital Markets and Securities Authority (CMSA). There are currently seventeen (17) listed firms of which five firms have cross listed from the NSE to the DSE, including NMG, Kenya Airways, Kenya Commercial Bank (KCB), Jubilee Holdings, and EABL.

The third securities exchange in the EAC is the USE founded in June 1997. It is operated under the jurisdiction of Uganda's CMA which in return reports to the Bank of Uganda. The exchange opened for trading in 1998 and trading occurs Monday to Friday. There are currently 16 listings, seven of which are cross listed from the NSE, they include, NMG, Kenya Airways, KCB, Jubilee Holdings, EEABL, Equity Bank, Centum Investment Limited and Uchumi Supermarkets. Umeme with a primary listing in the USE cross listed to the NSE in 2013.

The Rwanda Stock Exchange is the youngest Stock Exchange in the region and opened for business on $31^{\text {st }}$ January 2011 succeeding from the operations of the Rwanda over the Counter Exchange opened in January 2008. There are currently 3 firms cross listed from the NSE; Nation media Group, Uchumi Supermarkets and Kenya Commercial Bank in 2009 and 2010 respectively (Onyuma et al, 2012). The emerging integration of East African securities markets tocks has eased and encouraged firms to cross list in the region which will be finalized once the appropriate regulatory framework is in place. The markets in the region aim to facilitate the availability of listed securities in the four markets and cross listing is seen as a key activity to achieving this objective. 


\subsection{Why Firms Cross List their Shares}

Firms will cross list for different reasons as shown by available literature. D'Souza et al. (2005) observed that firms will cross list for various reasons such as; to gain liquidity and avoid cross border barriers of investment, to have access to capital from another market and also bond themselves to markets with stronger shareholder protection. Investor protection is poor in many countries as shown by La Porta et al. (1998), which carries significant economic consequences such as low external finance, share prices and under developed financial markets. This motivates firms in markets with poor investor protection to cross list in other markets which bonds them to better investor protection (Stulz, 1999). William et al. (2002) note that firms from countries with weak investor protection regimes are more likely to cross-list in the US, while firms that have a large controlling shareholder are less likely to cross-list (Doidge et al., 2006). With Kenya having weak investor protection laws, Kenyan firms will cross list in markets that have better investor protection such as Rwanda which has better regulations in terms of investor protection in the region.

Onyuma et al. (2012) notes that cross listing is also beneficial for the firm and country of secondary listing. In addition to increasing stock market liquidity, cross listing also provides an avenue for portfolio diversification for a wider investor base, improves employment levels through gains from the expansion in operations in the country of secondary listing, enhances both the business reputation of the cross listed firm and other national listed firms, reduces spreads on interest rates and debt securities by increasing the number of investors in the stock market thereby reducing the concentration of investors in the money market, increases the availability and accuracy of public information and lowers information asymmetries and enhances corporate governance, market transparency and quality.

Adelegan (2009) using event study methodology found that there are positive abnormal returns around the date of the regional cross-listing of stocks. The positive announcement period effect, together with the normal post cross listing performance shows that regional cross listing increases firm value and that a firm benefits from listing outside their home market. This shows that firms in the region will be encouraged to cross list hoping to increase their value. Cross border listing in Africa is also influenced by policy, for instance many South African companies listing on the Namibia Stock Exchange (NSX) has been motivated by the imposition of capital controls on portfolio flows and by the domestic investment requirements set by the Namibian authorities in an attempt to keep the large surpluses of the country's pension and insurance funds invested in Namibia. By cross listing, South African firms were able to qualify as Namibian investments. Similarly, the cross listing of EABL on the Ugandan and Tanzanian exchanges was linked to ensuring market access for beer trade throughout the EAC. Other policies that can act as incentives for firms to cross list include reductions in the transaction and approval costs of regional cross listing and relaxation of stringent cross listing requirements.

Liquidity is another reason why firms cross list as it is seen as a major motivator for firms to cross list because before cross listing firms have to contend with the liquidity in the primary market which in this case is the NSE which may not satisfy the firms financing needs and thus cross listing to broaden its shareholder base and access to funds from more than one market. Mitoo (1992) surveyed 78 managers from Canadian firms listed on different stock exchanges around the world and reported that increasing liquidity through increase in traded volume is regarded as the most targeted benefit from cross listing.

Cross listing provides a firm with an opportunity to improve its corporate governance. It is a vehicle through which a firm's management can 'bond' themselves to a legal system with more protections against management selfdealing or excessive consumption of private benefits of control, Burns and Bill (2006). Cross listing, helps improve on corporate governance. This is true for firms that originate from relatively less-developed country with weaker institutions. For instance, firms from Africa that cross-list on the American market have to maintain the standards of the American system. This in essence will improve their governance practices. The higher standards lead to more disclosure and better information, which gives the shareholders greater influence and protect minority shareholders more fully thus improving the ability to create value for shareholders (Mugo, 2010).

\subsection{Cross Border Listing in Africa}

Cross border listing has existed in Africa for a while, although this is usually done regionally. Adelegan (2009) observed that cross listing was started by the Johannesburg Securities Exchange (JSE) of South Africa when it cross listed on the NSX on the first day of trading of the NSX in October 1992. Subsequently, South Africa has cross-listed 28 firms on the NSX. There has also been regional cross-listing between stock markets in Botswana and South Africa since 1997; Malawi and South Africa in 1999; Nigeria and South Africa first in 2001 and later in 2006; Zambia and South Africa in 2003; and Ghana and South Africa in 2004. Triple listing of stocks has also commenced, with the three East African Exchanges of Kenya, Uganda and Tanzania in 2004; where NMG, KCB Group, EABL, Kenya Airways and Jubilee Holdings, which are primarily listed on the NSE, are also cross-listed on the USE and DSE, while NMG and KCB Group are also cross-listed on the RSE (Onyuma, 2006). South Africa has signed a MoU with Botswana, Egypt, Ghana, Kenya, Namibia, Nigeria, and Uganda. Nigeria has signed a MoU with Ghana and WAEMU, while the NSE of Kenya has signed MoUs with Ghana, Nigeria, Tanzania, Uganda, and WAEMU (Onyuma et al. 2012). In Sub Saharan Africa countries, regional cross-listing is beneficial to the firms and to the countries of both primary listing (home country) and secondary listing (host country). Policy makers of the countries of primary and secondary listings need the 
right policies to encourage, facilitate and steer regional crosslisting efforts by firms. Through complementary policy based efforts, policy makers can set the stage for the regional cross listing of stocks and harness the numerous benefits that are associated with it (Adelegan, 2009).

Regional cross-listings in Sub-Saharan Africa have been associated with expansion and the setting up of operations in the host countries. In almost all cases, firms are large with a strong base in their home countries, and they first established operations in their host countries before deciding to cross-list. Many cross-listings are undertaken to expand operations in the host countries. For example, EABL, with Kenya as the home country, has a subsidiary Uganda Breweries Ltd in Uganda, its host country of cross-listing. Jubilee Insurance of Kenya has subsidiaries in Uganda and Tanzania; Kenya Airways owns 49 percent of Precision Air of Tanzania; Ecobank Transnational has operations in the Cote D'Ivoire the home country and in Ghana and Nigeria, the host countries; Investec and Ellerine have operations in South Africa and Botswana; and the 28 firms that are cross-listed in South Africa and Namibia have an operational base in both countries. Cross-listing in sub-Saharan Africa has been generally accompanied by an initial public offering and/or secondary market listing (Onyuma et al. 2012).

In the EAC, cross listing across national stock exchanges in Kenya, Tanzania, Uganda and Rwanda is seen as a means to regional integration. Integration of the capital markets means that investors will buy and sell securities in any East African stock market without restriction. Participants in capital markets will freely offer their services throughout East Africa and those identical securities will trade at essentially the same price across markets after foreign exchange adjustments. According to Onyuma et al. (2012) it is now easier to cross-list in the East African Bourse due to the following incentives: First there are no requirements of reporting accountants report. Second, only a summarized information memorandum is required. Third incentive is that an abridged financial statement for the last five years is acceptable. Fourth, provision of the latest annual or interim accounts submitted to the home exchange would be accepted as the latest financial statements. Finally, standard initial cross-listing fee of US\$5,000 against previous US\$21,126 has been set for firms listing their equities across Kenya and Uganda borders.

Cross border listing has gained significance over the past few years since the signing of the East Africa Community treaty in 1999. The development of cross listing across national stock markets in Tanzania, Kenya, Uganda and Rwanda is a milestone in the EAC's drive for regional integration. The three East African Stock Exchanges have established a working relationship among them in the spirit of integrating and developing capital markets in the EAC. The exchanges operate under the umbrella of East African Stock Exchanges Association (EASEA) with the objective of integrating trading, clearing and settlement infrastructures within the EAC to facilitate a faster trading system. A key first step is improving inter-connectedness of the regional securities exchanges. EASEA is a member of Capital Markets Development Committee (CMDC) of the EAC. Other members of the CMDC include East African Securities Regulatory Association (EASRA) and East African Stock Exchange Brokers Association (EASBA). The three associations have the common objective of integrating the three markets in order to achieve growth of the market with the ultimate aim of economic union in the EAC. The three markets are aiming at achieving this objective in a systematic, coordinated manner that will facilitate the availability of listed securities in the three markets simultaneously. To this end EASEA has determined mass cross listing as the key activity that will achieve this objective (Onyuma et al., 2012).

The East African Member States Securities and Regulatory Authorities (EASRA) comprising capital market authorities of Kenya, Tanzania, and Uganda ware established on March 5, 1997 through the signing of an MOU. It was set up with the objective of establishing a framework for mutual cooperation in the area of capital market development, harmonization of securities laws, and promotion of information-sharing and cooperation among members. The geography of cross listing has changed considerably with Kenya Airways (KQ), EABL, Jubilee Insurance Holding, Equity Bank, KCB, NMG, and Centum, which are Kenyan firms, listing in Uganda, Tanzania and Rwanda (Onyuma et al., 2012).

\subsection{Relationship between Cross Listing and Stock Liquidity}

Liquidity is the lifeblood of financial markets. Its adequate provision is critical for the smooth operation of an economy. Its sudden erosion in even a single market segment or in an individual instrument can stimulate disruptions that are transmitted through increasingly interdependent and interconnected financial markets worldwide (Rico, 2004). If there is no liquidity at all in the market, no trading can take place. In a liquid market there exist at least one bid and one ask quote that make a trade possible and it is also possible to trade a certain amount of shares with little impact on the quoted price. Liquidity is important to stock exchanges and investors because it enables the following; time trading which is the ability to execute a transaction immediately at the prevailing price, tightness defined as the ability to buy and to sell an asset at about the same price at the same time, depth which is the ability to buy or to sell a certain amount of an asset without influence on the quoted price and lastly, resiliency which is the ability to buy or to sell a certain amount of an asset with little influence on the quoted price.

Companies value share liquidity for a number of reasons as observed by William (2009). First, liquid stock can be used as currency for acquisitions. This allows a public company to pursue an acquisition even if it lacks sufficient cash or borrowing capacity. Second, a company can use liquid stock as a component of employee compensation. Liquid stock is attractive to employees because it can be easily valued and converted into cash, and it provides tax benefits and upside potential. These considerations aid in employee recruitment and retention and better align the interests of employees and shareholders. Third, fluctuations 
in the price of a company stock in a liquid market aids management because it provides immediate feedback as to the market consensus on the company's strategy and performance.

Karolyi (1998) looked at why companies list abroad and reported that liquidity of shares improves overall but depends on the increase in total trading volume, the listing location and the scope of foreign ownership restrictions in the primary market. Important liquidity effects are observed with cross listing. Typically stocks experience an increase in total trading volume and a decrease in home market spreads due to in large part to the competition from the new market captures. The extend of liquidity enhancement, however depends on the proportion of total trading volume the new market captures and the trading restrictions imposed on foreigners in those stocks prior to cross listing, (Karolyi, 1998).

Amihud and Mendelson (1989) indicate that investors require higher returns to hold stocks with lower liquidity to compensate them for higher transaction costs. This will negatively impact on the stock making it expensive and thus undesirable to investors. By cross listing the firm should be able to increase the liquidity of its stock which in turn brings down the price and makes the stock more attractive to investors in both the primary market and secondary markets. Increased liquidity, other factors held constant, should translate into a lower cost of equity capital because it reduces the costs of trading for investors and therefore reduces the required illiquidity premium (Brennan et al., 1998 and Jacoby et al, 2000).

There are other factors that affect share liquidity other than cross border listing as noted by Shuenn (2007), who looked at factors affecting stock liquidity and identified firm size, compression of ownership structure, level of information asymmetry, utilization rate of margin trading, absorbed stocks of investors, and the entire market's liquidity as the factors affecting liquidity. He reported that, the firm size is positively related to liquidity, the more scattered ownership structure is, the higher the liquidity will be, the more critical information asymmetry is, the lower the stock liquidity will be, the higher margin trading utilization is, the higher the stock liquidity will be, the liquidity of an individual stock is positively related to the liquidity of the entire market and the more investor's perceptions are absorbed, the higher the stock liquidity will be.

\section{Methodology}

\subsection{Sampling and Data Collection}

An event study methodology was utilized in this study because it is a technique of empirical finance research that enables a researcher to assess the impact of a particular event taking place in a firm. This study focused on stocks cross listed in other EAC markets from the NSE in the last five (5) years where data on traded volume was available for a year before and a year after cross listing. Due to the small size of cross listed firms in the EAC a census study was carried out covering all companies that have cross listed in the last five years. The four companies sampled were KCB, Equity Bank, NMG and Centum Investments. Data for Jubilee Holdings could not be obtained for analysis. Data was collected from the NSE related to shares traded and stock prices of the firms in the sample and used in the analysis.

\subsection{Data Analysis}

Traded volume and turnover were used as measures of liquidity. The volume related liquidity measures can be calculated as a certain volume, or quantity of shares per time unit. Usually volume related liquidity measures are used to capture depth dimension of liquidity, but there is also a relation to the time dimension since higher volume in the market leads to a shorter time needed for trading a predefined amount of shares (Rico, 2004). Trading volume per time interval $\left(Q_{t}\right)$ is incorporated in many liquidity studies such as Foerster and Karolyi (1998) and Dennis and Strickland (2002).

Trading volume for time $\mathrm{t}-1$ until time $\mathrm{t}$ was calculated as follows:

$$
Q_{t}=\sum_{i=1}^{N_{t}} q_{i}
$$

Where; $\mathrm{N}_{\mathrm{t}}-$ denotes the number of trades between $\mathrm{t}-1$ and $\mathrm{t}$ $\mathrm{q}_{\mathrm{t}}$ - Is the outstanding number of shares of trade.

Like the trading volume, turnover $\left(\mathrm{V}_{\mathrm{t}}\right)$ had to be calculated for a specific time interval, this was calculated as follows;

$$
V_{t}=\sum_{i=1}^{N_{t}} p_{i} \cdot q_{i}
$$

Where; $\mathrm{P}_{\mathrm{t}}-$ denotes the price of trade.

$\mathrm{N}_{\mathrm{t}}$ - is the number of trades between $\mathrm{t}-1$ and $\mathrm{t}$

$\mathrm{q}_{\mathrm{t}}-$ is the outstanding number of shares of trade.

Trading volume and turnover only need trades as data input which makes them easy to calculate. The turnover per time unit has the advantage that it makes different shares comparable to each other. It is not biased by the absolute share price. After calculating the traded volume and turnover for each month for a period of twelve months prior to cross listing and twelve months post cross listing as shown above, mean for traded volume and turnover were calculated following Dennis and Strickland (2002). These were tested for significance using a paired $\mathrm{t}-$ test at five percent level.

\section{Results and Discussion}

\subsection{Traded Volume Before and after Cross Listing}

\subsubsection{Equity Bank}

After cross listing the volume traded increased from a mean of 9.6 million shares to a mean of 41.1 million shares one year after cross listing representing a percentage change of $351 \%$. The increase is statistically significant as shown by the p-value of 0.0002 which is less than the level of significance level of 0.05 . 
Table 1. Equity Bank.

\begin{tabular}{llllll}
\hline & Mean Before & Mean After & T Stat & Df & P-value \\
\hline VOLUME & $9,659,922$ & $41,136,901$ & 5.447 & 11 & 0.000 \\
MAX PRICE & 198 & 18 & 5.883 & 11 & 0.000 \\
MIN PRICE & 136 & 14 & 4.509 & 11 & 0.001 \\
AVG PRICE & 170 & 17 & 5.395 & 11 & 0.000 \\
\hline
\end{tabular}

Mean Before - 12 months before cross listing (June 2008- May 2009)

Mean After - 12 months after cross listing (June 2009- May 2010)

\subsubsection{Nation Media Group}

Volume traded increased after cross listing as shown by the mean of 477,550 shares for the year before cross listing and mean of 770,652 for the year after cross listing, representing a percentage change of $61.4 \%$. This increase however is not statistically significant as evidenced by the $p$ value of 0.236942 being greater than 0.05 .

Table 2. Nation Media Group.

\begin{tabular}{llllll}
\hline & Mean - Before & Mean - After & T Stat & Df & P-value \\
\hline VOLUME & 477,550 & 770,652 & 1.251 & 11 & 0.237 \\
MAX PRICE & 143 & 173 & 4.576 & 11 & 0.001 \\
MIN PRICE & 121 & 148 & 4.555 & 11 & 0.001 \\
AVG PRICE & 135 & 165 & 4.609 & 11 & 0.001 \\
\hline
\end{tabular}

Mean Before: 12 months before cross listing (Oct 2009 - Sept 2010)

Mean After: 12 months after cross listing (Oct 2010 - Sept 2011)

\subsubsection{Centum Investments}

Traded volume increased after cross listing as shown by the increase in mean from 1.76 million shares to over 4.47 million shares year after cross listing representing a percentage change of $150 \%$. The increase in volume traded is statistically significant as evidenced by the $\mathrm{p}$ - value of 0.000469179 being less than 0.05 .

Table 3. Centum Investment

\begin{tabular}{llllll}
\hline & Mean 1 & Mean 2 & T Stat & Df & P-value \\
\hline VOLUME & $1,757,405$ & $4,469,058$ & 4.903 & 11 & 0.000 \\
MAX PRICE & 14 & 22 & 7.148 & 11 & 0.000 \\
MIN PRICE & 10 & 18 & 7.563 & 11 & 0.000 \\
AVG PRICE & 12 & 20 & 7.625 & 11 & 0.000 \\
\hline
\end{tabular}

Mean Before:12 months before cross listing (Feb 2009 - Jan 2010)

Mean After: 12 months after cross listing (Feb 2010 - Jan 2011)

\subsubsection{Kenya Commercial Bank}

Volume traded declined after cross listing from a mean of 24.6 million shares to 16.6 million shares after cross listing, representing a percentage change of $-32 \%$. The decrease in traded volume is not statistically significant since the $p$ value of 0.286324 is greater than the 0.05 .

Table 4. Kenya Commercial Bank.

\begin{tabular}{llllll}
\hline & Mean Before & Mean After & T Stat & Df & P-value \\
\hline VOLUME & $24,626,423$ & $16,576,762$ & 1.121 & 11 & 0.286 \\
MAX PRICE & 26 & 23 & 2.252 & 11 & 0.046 \\
MIN PRICE & 15 & 18 & 1.420 & 11 & 0.183 \\
AVG PRICE & 22 & 21 & 1.309 & 11 & 0.217 \\
\hline
\end{tabular}

Mean Before: 12 months before cross listing (June 2008 - May 2009)

Mean After: 12 months after cross listing (June 2009 - May 2010)

\subsubsection{Overall Impact of Cross Listing on Traded Volume}

Traded volume of the four firms in the study increased from a mean of 9 million shares year before cross listing to a mean of 16 million shares year after cross listing, representing a percentage change of $77.8 \%$. This increase in shares traded was statistically significant as shown by the pvalue of 0.0049 which is less than the level of significance 0.05 .

Table 5. Overall Traded Volume.

\begin{tabular}{llllll}
\hline & Mean Before & Mean After & T Stat & Df & P-value \\
\hline VOLUME & $9,130,325$ & $15,738,343$ & 0.768 & 3 & 0.0049 \\
MAX PRICE & 95 & 59 & 0.748 & 3 & 0.0050 \\
MIN PRICE & 70 & 50 & 0.617 & 3 & 0.5806 \\
AVG PRICE & 85 & 56 & 0.697 & 3 & 0.5356 \\
\hline
\end{tabular}

Mean Before: 12 months before cross listing

Mean After: 12 months after cross listing

\subsection{Turnover Before and after Cross Listing}

\subsubsection{Equity Bank}

Turnover for Equity Bank declined from a mean of 895 million shares in the year before cross listing to a mean of 692 million shares a year after cross listing, representing a percentage change of $-22.7 \%$. The decline in turnover is observed because even though volume traded increased after cross listing, average price declined from a mean of sh. 170 to a mean of sh. 17 after cross listing, representing a percentage change of $-90.3 \%$. The decline in turnover however is not statistically significant since the p-value of 0.397 is greater than the level of significance of 0.05 .

Table 6. Equity Bank Turnover.

\begin{tabular}{llllll}
\hline & Mean 1 & Mean 2 & T Stat & Df & P-value \\
\hline TURNOVER & $894,567,756$ & $692,158,202$ & 0.881 & 11 & 0.397 \\
MAX PRICE & 198 & 18 & 5.883 & 11 & 0.000 \\
MIN PRICE & 136 & 14 & 4.509 & 11 & 0.001 \\
AVG PRICE & 170 & 17 & 5.395 & 11 & 0.000 \\
\hline
\end{tabular}

Mean Before: 12 months before cross listing (June 2008- May 2009) Mean After: 12 months after cross listing (June 2009- May 2010)

\subsubsection{Nation Media Group}

Turnover for NMG increased from a mean of 6.6 million year before cross listing to 1.2 billion for year after cross listing, representing a percentage change of $81.8 \%$. The increase in mean is not statistically significant as evidenced by the p-value of 0.125537 being greater than 0.05 .

Table 7. Nation Media Group.

\begin{tabular}{llllll}
\hline & Mean 1 & Mean 2 & T Stat & Df & P-value \\
\hline TURNOVER & $66,322,959$ & $1,236,542,237$ & 1.658 & 11 & 0.126 \\
MAX PRICE & 143 & 173 & 4.576 & 11 & 0.001 \\
MIN PRICE & 121 & 148 & 4.555 & 11 & 0.001 \\
AVG PRICE & 135 & 165 & 4.609 & 11 & 0.001 \\
\hline
\end{tabular}

Mean Before: 12 months before cross listing (Oct 2009 - Sept 2010)

Mean After: 12 months after cross listing (Oct 2010 - Sept 2011) 


\subsubsection{Centum Investments}

Turnover for Centum Investment increased after cross listing from a mean of 21.3 million year before gross listing to a mean of 94.7 million year after cross listing, representing a percentage change of $345.4 \%$. This increase is statistically significant since the p- value of 0.000086 is less than 0.05 . Centum shares liquidity increased significantly based on turnover which increased significantly after cross listing.

Table 8. Centum Investment

\begin{tabular}{llllll}
\hline & Mean Before & Mean After & T Stat & Df & P-value \\
\hline TURNOVER & $21,294,020$ & $94,701,747$ & 6.026 & 11 & 0.000 \\
MAX PRICE & 14 & 22 & 7.148 & 11 & 0.000 \\
MIN PRICE & 10 & 18 & 7.563 & 11 & 0.000 \\
AVG PRICE & 12 & 20 & 7.625 & 11 & 0.000 \\
\hline
\end{tabular}

Mean Before: 12 months before cross listing (Feb 2009 - Jan 2010)

Mean After: 12 months after cross listing (Feb 2010 - Jan 2011)

\subsubsection{Kenya Commercial Bank}

Turnover for KCB declined from 494.5 million to 356.8 million year after cross listing, representing a percentage change of $-27.9 \%$. This decline in turnover is also not statistically significant as evidenced by the $p$ value of 0.288123 being greater than 0.05 .

Table 9. Kenya Commercial Bank.

\begin{tabular}{llllll}
\hline & Mean Before & Mean After & T Stat & Df & P-value \\
\hline TURNOVER & $494,506,667$ & $356,769,698$ & 1.116 & 11 & 0.288 \\
MAX PRICE & 26 & 23 & 2.252 & 11 & 0.046 \\
MIN PRICE & 15 & 18 & 1.420 & 11 & 0.183 \\
AVG PRICE & 22 & 21 & 1.309 & 11 & 0.217 \\
\hline
\end{tabular}

Mean Before: Mean for the first 12 months before cross listing (June 2008 May 2009)

Mean After: Mean for the first 12 months after cross listing (June 2009 -

May 2010)

Source: Data Analysis 2015

\subsubsection{Overall Impact of Cross Listing on Turnover}

Turnover for the four firms on the other had declined from a mean of 369 million year before cross listing to a mean of 317 million year after cross listing, representing a percentage change of $-14.1 \%$. Since traded volume which is used to compute turnover increased after cross listing, the decline in turnover is explained by the decrease in average price mean from sh. 85 year before cross listing to a mean of sh. 56 year after cross listing, representing a percentage change of $34.1 \%$. This decrease in average price may have been caused by other factors in the market. However the decrease in turnover after cross listing is not statistically significant since the $\mathrm{p}$-value is greater the level of significance 0.05 .

Table 10. Overall Impact on Turnover.

\begin{tabular}{llllll}
\hline & Mean before & Mean After & T Stat & Df & P-value \\
\hline DEALS & 2,785 & 3,584 & 0.3153 & 3 & 0.773 \\
TURNOVER & $369,172,851$ & $316,657,412$ & 0.2516 & 3 & 0.503 \\
MAX PRICE & 95 & 59 & 0.7484 & 3 & 0.005 \\
MIN PRICE & 70 & 50 & 0.6174 & 3 & 0.581 \\
AVG PRICE & 85 & 56 & 0.6974 & 3 & 0.536 \\
\hline
\end{tabular}

Mean Before: Overall mean for the first 12 months before cross listing

Mean Africa: Overall mean for the first 12 months after cross listing

\subsection{Share Liquidity before and after Cross Listing}

\subsubsection{Equity Bank}

After cross listing, share liquidity for Equity Bank increased by $351 \%$. The increase is statistically significant as shown by the p-value of 0.0002 which is less than the level of significance level of 0.05 . This implies that cross listing of Equity shares had a positive impact on their liquidity when measured based on traded volume.

On the other hand when measured by turnover, liquidity for Equity Bank decreased by $-22.7 \%$. The decline is observed because even though volume traded increased after cross listing average price declined from a mean of sh. 170 to a mean of sh. 17 after cross listing, representing a percentage change of $-90.3 \%$. The decline in liquidity however is not statistically significant since the p-value of 0.397 is greater than the level of significance of 0.05 . Thus the shares liquidity declined as measured using turnover.

\subsubsection{Nation Media Group}

When measured by traded volume liquidity increased by $61.4 \%$ after cross listing. This increase however is not statistically significant as evidenced by the $\mathrm{p}$ value of 0.237 being greater than 0.05 . This means that although the liquidity of MNG shares increased as measured based on traded volume after cross listing, the increase was too small to be statistically significant. Therefore cross listing of NMG shares had a positive impact on their liquidity based on traded volume, however that impact was not statistically significant.

Based on turnover liquidity of NMG shares increased by $81.8 \%$ after cross listing. The increase is not statistically significant as evidenced by the p-value of 0.125 being greater than 0.05 . Thus liquidity for NMG shares increased after cross listing based on turnover. Therefore cross listing of NMG shares had a positive impact on its shares liquidity based on turnover, however that impact was not statistically significant.

\subsubsection{Centum Investments}

As for Centum, liquidity increased by $150 \%$ after cross listing when measured by traded volume. The increase in liquidity is statistically significant as evidence by the $\mathrm{p}$ - value of 0.0004 being less than 0.05 . This implies that Centum shares experienced the biggest increase in their liquidity and the increase was statistically significant making them easily tradable compared to the other firms. Thus based on traded volume cross listing had a positive impact on Centum's share liquidity which was statistically significant.

On the other hand share liquidity increased as measured by turnover by $345.4 \%$. This increase is statistically significant since the p- value of 0.000086 is less than 0.05 . Centum share liquidity increased significantly based on turnover significantly after cross listing. Thus cross listing of Centum's shares had a positive impact on their liquidity based on turnover. The positive impact was also statistically significant. 


\subsubsection{Kenya Commercial Bank}

Share liquidity for $\mathrm{KCB}$ decreased by $-32 \%$ after cross listing based on traded volume. The decrease in liquidity is not statistically significant since the p value of 0.286324 is greater than the 0.05 . Therefore cross listing of KCB shares had a negative impact on their liquidity based on volume, however the negative impact is not statistically significant. Liquidity also declined based on turnover by $-27.9 \%$ after cross listing. This decline in liquidity is not statistically significant as evidenced by the $p$ value of 0.288123 being greater than 0.05 . Therefore cross listing of KCB shares had a negative impact on their liquidity based on turnover, however the negative impact is not statistically significant.

Overall, for the four companies, their combined liquidity increased after cross listing based on traded volume by $77.8 \%$. This increase in shares traded was statistically significant as shown by the p-value of 0.0049 which is less than the level of significance 0.05 . Thus for the cross listed firms cross listing had a positive impact on their share's liquidity; which was statistically significant. On the other hand based on turnover, liquidity decreased after cross listing by $-14.1 \%$. the decline is mostly explained by the decrease in average price mean from sh. 85 year before cross listing to a mean of sh. 56 year after cross listing, representing a percentage change of $-34.1 \%$. This decrease in average price may have been caused by other factors in the market. However the decrease in liquidity after cross listing is not statistically significant since the p-value is greater the level of significance 0.05 . Thus based on turnover, cross listing of the firms shares had a negative impact on their liquidity, however this impact is not statistically significant.

It is therefore evident that the traded volume increased for three firms, namely; Centum, Equity Bank and NMG. These findings are consisted with those of Foerster and Karolyi (1998). Bancel and Mitoo (2001) also report that, on the basis of survey done with Canadian and European firms that cross listing increases the total trading volume of the share of the firm in the primary market which in this case is the NSE. The increase is as a result of cross-listing increasing trading hours and the number of traders that have economic interest in the stock and, therefore, facilitates competition among traders. The changes in trading volume can also be attributed to factors such as changes in ownership after cross listing as shown by Doidge (2004).

Share liquidity improved for NMG and Centum when measured by turnover and for Equity Bank, NMG and Centum measured by traded volume. Of this only liquidity for Equity Bank and Centum were statistically significant. These results mirror those of Domowitz et al., (1998) and Foerster and Karolyi, (1998), who reported that liquidity of shares improves overall but that depends on the increase in total trading volume, the listing location and the scope of foreign ownership restrictions in the primary market. The increased liquidity after cross listing means that the shares of the mentioned companies can be converted to cash easily and without a significant loss in value, hence making the companies more attractive to investors.
However this is not always the case as shown by Kenya Commercial Bank share liquidity decline after cross listing when measured by traded volume and Equity Bank and KCB when measured by turnover. The decline in share liquidity after cross listing was also observed by Domowitz et al., (1998) and Silva and Cha'vez, (2008) meaning that investors cannot easily convert their shares into cash without a significant impact on the share price, hence making the shares less desirable to investors after cross listing.

\section{Conclusions}

In conclusion traded volume increased for Centum, Equity Bank and Nation Media Group which is consisted with the findings of Foerster and Karolyi (1993). Traded volume on the other hand declined for KCB. Of these results Equity Bank and Centum Investments were statistically significant while those of $\mathrm{KCB}$ and NMG were not statistically significant.

After cross listing turnover increased for Nation Media Group and Centum Investments while it declined for Equity Bank and KCB. The Equity Bank, Nation Media Group and $\mathrm{KCB}$ findings were not statistically significant, while those for Centum Investments were statistically significant.

Share liquidity improved for NMG and Centum when measured by turnover and for Equity Bank, NMG and Centum Investments measured by traded volume. Of this only liquidity for Equity Bank and Centum were statistically significant. These results mirror those of Domowitz et al., (1998) and Foerster and Karolyi, (1998) who reported that improvement in liquidity of shares depends on the increase in total trading volume, the listing location and the scope of foreign ownership restrictions in the primary market. The increased liquidity after cross listing means that the shares of the mentioned companies can be converted to cash easily and without a significant loss in value, hence making the companies more attractive to investors.

However this is not always the case as shown by $\mathrm{KCB}$ share liquidity decline after cross listing when measured by traded volume and Equity Bank and KCB when measured by turnover. The decline in share liquidity after cross listing was also observed by Domowitz et al., (1998) and Silva and Cha'vez, (2008) meaning that investors cannot easily convert their shares into cash without a significant impact on the share price, hence making the shares less desirable to investors after cross listing. From the results of the study, it can be generally concluded that cross listing generally impacts a firm's shares liquidity both positively and negatively according to the measure of liquidity utilized, although in most cases that impact is not statistically significant.

\section{Recommendations for Policy}

Based on the findings, the study recommends that firm managers should consider cross-list for other reasons, probably such as penetration of new markets, investor 
awareness, but not for improving share liquidity since most of the changes in liquidity were not statistically significant. Future research may consider assessing the effect of crosslisting on market depth, tightness and resilience independently.

\section{References}

[1] Adelegan, O. J. (2009). The Impact of the Regional Cross Listing of Stocks on Firm Value in Sub-Saharan Africa. IMF Working Paper. IMF WP/09/99.

[2] Amihud, Y. and Mendelson, H. (1989). The Effects of Beta, Bid-Ask Spread, Residual Risk, and Size on Stock Returns. The Journal of Finance, Vol. 44, pg. 479-486.

[3] Bancel, F. and Mittoo, U.R. (2001). European Managerial Perceptions of the Net Benefits of Foreign Stock Listings. European Financial Management, Vol. 7, pg. 213-236.

[4] Brennan, M. J. Chordia, T. and Subrahmanyam, A. (1998). Alternative Factor Specifications, Security Characteristics, and the Cross-Section of Expected Stock Returns. Journal ofFinancial Economics, Vol.49 (3): pg. 345-373.

[5] Burns, N. and Bill, F. (2006). Cross Listing and Legal Bonding: Evidence from Mergers and Acquisitions, University of Georgia. New York. Available at; ttp://www.ceistorvergay.it/conferenzconvergin/banking\&finan ce

[6] D'Souza, J. Robert, N. and William, M. (2005). Effect of Institutional and Firm-Specific Characteristics on PostPrivatization Performance: Evidence from Developed Countries, Journal of Corporate Finance Vol. 11, pg. 747-766.

[7] Dennis, P. and D. Strickland (2002), The Effect of Stock Splits on Liquidity and Excess Returns: Evidence from Shareholder Ownership Composition, forthcoming in the Journal of Finance.

[8] Doidge, C. (2004). U.S. Cross- Listings and the Private Benefits of Control: Evidence from Dual-Class Firms. Journal of Financial Economics, Vol. 72, pg. 519-553.

[9] Doidge, C. Karolyi, G. Karl, V. Miller, P. and Stulz, R. (2006). Private Benefits of Control, Ownership, and the Cross-Listing Decision. Working Paper SeriesNo.2, Charles A. Dice Center for Research in Financial Economics, Ohio State University.

[10] Domowitz, I., J.Glen, A. Madhavan,(1998) International Cross-Listing and Order Flow Migration: Evidence from an Emerging Market, the Journal of Finance, Vol. 53, No. 6: 2001-2027.
[11] Foerster, S. R. and Karolyi, G. A. (1998). Multimarket Trading and Liquidity: A Transaction Data Analysis of Canada U.S. Inter Listings, Journal of International Financial Markets, Institutions and Money Vol. 8: 393-412.

[12] Jacoby, G. Fowler, D. J. and Gateman, A. A. (2000). The Capital Asset Pricing Model and the Liquidity Effect: A Theoretical Approach. Journal of Financial Markets, Vol. 3 (1): 69-81.

[13] Karolyi, G.A. (1998). Why Do Companies List Shares Abroad? A Survey of the Evidence and Its Managerial Implications. Institutions \& Intrument, 7, New York, University Salomon Center.

[14] La Porta, R., L'opez-de Silanes, F., and Shleifer, A. (1998), Law and Finance, Journal of Political Economy Vol. 106: 1113-1155.

[15] Levine, R and Schmukler, S. (2003). Migration, Spillover and Trade Diversion: The Impact of Internationalization on Stock Market Liquidity, University of Minnesota working Paper.

[16] Mittoo, U., (1992). Managerial perceptions of the net benefits of foreign listing: Canadian evidence. Journal of International Financial Management and Accounting Vol. 4: 40-62.

[17] Onyuma, S. O. (2006) Regional Integration of Stock Exchanges in Africa. African Review of Money Finance \& Banking, Supplementary Issue of Savings \& Development:97122.

[18] Onyuma, S. O., Mugo, R. K. and Karuitha, J. K. (2012). Does Cross Border Listing (Still) Improve Financial Performance In Eastern Africa? Journal of Business, Economic And Finance. Vol. 1, issue 1: 92-109.

[19] Rico, V. W. (2004). Measuring and Predicting Liquidity in the Stock Market; University of St. Gallen, Dissertation No. 2899.

[20] Rosenboom and Van D. (2009), The Market Reaction to Cross-Listings: Does the Destination Market Matter? Journal of Banking and Finance, Vol. 33: 1898-1908.

[21] Shuenn, R. C. (2007). A Study on the Factors Affecting Stock Liquidity. International Journal of Services and Standards. Vol. 3 No. 4: 453-475.

[22] Silva, A.C. and Chavez, G.A. (2008), Cross-Listing and Liquidity in Emerging Market Stocks, Journal of Banking and Finance, Vol. 32 No. 3: 420-433.

[23] Stulz, R. (1999). Globalization, Corporate Finance and the Cost of Capital, Journal of Applied Corporate Finance, Vol. 26: 3-28.

[24] William A.J. and Weisbach, S., Reese. (2002). Protection of Minority Shareholder Interests, Cross Listing in The United States And Subsequent Equity Offerings, Journal of Financial Economics, vol. 66: 65-104. 